\title{
Building up the English language listening skill through M-Learning tools. A preliminary study
}

\section{Desarrollar la habilidad de escucha del idioma inglés a través de herramientas de M-Learning. Un estudio preliminar}

1 Ana Jazmina Vera de la Torre

https://orcid.org/0000-0003-4698-6242.

Universidad Técnica de Ambato, Facultad de Ciencias Humanas y de la Educación,

Ambato-Ecuador

aj.vera@uta.edu.ec

2 Valeria Carolina Mendoza Chavarria (iD) https://orcid.org/0000-0002-1314-9416

Universidad Técnica de Ambato, Facultad de Ciencias Humanas y de la Educación,

Ambato-Ecuador

v.mendoza1063@uta.edu.ec

3 Marbella Cumanda Escalante Gamazo (iD) https://orcid.org/0000-0002-3179-8102.

Universidad Técnica de Ambato, Facultad de Ciencias Humanas y de la Educación,

Ambato-Ecuador

ma.escalante@uta.edu.ec

4 Dorys Maribel Cumbe Coraizaca (iD https://orcid.org/0000-0003-1818-5974

Universidad Técnica de Ambato, Facultad de Ciencias Humanas y de la Educación,

Ambato-Ecuador

dm.cumbe@uta.edu.ec

Artículo de Investigación Científica y Tecnológica

Enviado: 24/12/2021

Revisado: $29 / 12 / 2021$

Aceptado: $12 / 01 / 2022$

Publicado:08/03/2023

DOI: https://doi.org/10.33262/concienciadigital.v6i1.4.2045

Vera de la Torre, A. J., Mendoza Chavarria, V. C., Escalante Gamazo, M. C., \& Cumbe Coraizaca, D. M. (2023). Building up the English language listening skill through MLearning tools. A preliminary study. ConcienciaDigital, 6(1.4), 983-994. https://doi.org/10.33262/concienciadigital.v6i1.4.2045

CONCIENCIA DIGITAL, es una Revista Multidisciplinar, Trimestral, que se publicará en soporte electrónico tiene como misión contribuir a la formación de profesionales competentes con visión humanística y crítica que sean capaces de exponer sus resultados investigativos y científicos en la misma medida que se promueva mediante su intervención cambios positivos en la sociedad. https://concienciadigital.org

La revista es editada por la Editorial Ciencia Digital (Editorial de prestigio registrada en la Cámara Ecuatoriana de Libro con No de Afiliación 663) www.celibro.org.ec 


\section{Palabras} claves:

English listening, 6minute English, aplicaciones móviles, destreza auditiva, comprensión.

Keywords: mobile apps, English listening and 6minute English, listening skill.
Resumen

Introducción. El aprendizaje de una lengua extranjera requiere el manejo de ciertas habilidades y para lograrlo es necesario tomarse el tiempo, aplicar métodos y estrategias, y apreciar el proceso de aprendizaje significativo. Objetivo. El objetivo principal de esta investigación es evaluar las aplicaciones móviles Listening English y 6 Minute English en el desarrollo de la comprensión auditiva. Metodología. Esta investigación se desarrolló en la Unidad Educativa Prócer Manuel Quiroga en Santo Domingo, con 63 estudiantes en su tercer año de secundaria. Como primer paso, se realizó una encuesta entre profesores para identificar el problema. Resultados. Este trabajo utilizó investigación empírica con enfoques cualitativos y cuantitativos. Para recopilar información, se utilizó pruebas estandarizadas previas y posteriores a la prueba. Los estudiantes utilizaron la aplicación móvil durante dos meses. Se utilizó la prueba de Wilcoxon para analizar la información recopilada. Conclusión. Finalmente, los resultados mostraron que las aplicaciones móviles English Listening y 6 Minute English tuvieron un impacto positivo en el desarrollo de la comprensión auditiva. Su estructura, métodos y recursos resultaron muy atractivos para los estudiantes y han aprendido el idioma de forma eficaz. Estos factores hacen que los estudiantes y profesores se sientan cómodos y motivados para desarrollar sus habilidades auditivas.

\section{Abstract}

Introduction. In the sphere of education, mobile technology has taken on a significant role. There are numerous resources available to help us enhance our talents in areas that we are unfamiliar with. The primary goal of this research is to see how the English Listening and 6 Minute English mobile apps affect listening comprehension development. Objective. The goal of the study is to examine student acceptance of mobile technology as a methodology for learning English and building listening skills by evaluating the efficiency of the mobile apps based on improvements in students' listening skills after two months of use. Methodology. The research was conducted with 63 students from the third year of baccalaureate at the Unidad Educativa Prócer Manuel Quiroga in Santo Domingo City, Ecuador. The researcher employs standardized Pre-test and Post-Test to collect data. 
Results. The Wilcoxon test was used to assess all the data, and the results showed that the English Listening and 6 Minute English mobile apps had 95 percent favorable effects on the improvement of listening comprehension. Conclusion. Finally, it is concluded that English Listening and 6 Minute English are two mobile applications that teachers may trust and use to help students improve their listening comprehension. These programs offer a wide range of interactive, innovative, and instructive listening activities. Their systems are trustworthy and include accurate information that can be shared in a classroom setting. Based on the findings, teachers should use the English Listening and 6 Minute English mobile apps to help students improve their listening comprehension in English as a foreign language. Because of their originality, content, approach, and interest, these apps provide various and significant benefits to students.

\section{Introduction}

The English language has been designated as the official language for business and travel. According to research published in The Babbel Magazine, approximately 1.5 billion people speak this language, accounting for $20 \%$ of the world's population (Lyons, 2017). In many pluralistic circumstances and multilingual countries, English has obviously served as a language of broader communication. This language has served as a lingua franca, allowing for greater communication around the globe.

Despite the fact that Latin America invests in education, English proficiency remains low. According to the EF English Proficiency Index, Argentina has the highest English proficiency, with 56.51 percent, followed by Brazil (51.92\%), Chile (51.50\%), Colombia (49.47 percent), Ecuador (49.42 percent), Venezuela (45.71 percent), and El Salvador (45.70 percent), all of which are in the medium (Argentina) and very low (El Salvador) categories (El Salvador) (Cronquist \& Fiszbein, 2017).

Even though Ecuador is an average of $49.42 \%$, being in the last three positions from the 20 countries in Latin America; in the ranking of English Learning, in the English Language Learning Policy Framework, it has successfully addressed Legal Foundation, such as: a national plan or strategy and English being mandatory by law; Standards for Learning: teaching supports, curriculum and programs of study and standard objectives; Student achievement: proficiency goals and standard of measurement; and Teacher Qualifications: proficiency goals and assessment. So, as in can be noticed although we 
are in the technological era and we have the resources and materials to improve English skills, it is not being applied in our country.

Language development is one of the primary goals of education because it is the primary tool through which the human being constructs and comprehends the world around him and engages in dialogue with himself and others. Language is the physical manifestation of our thoughts; it connects us to others and makes us members of a cultural community (Irzsa, 2012). As evidenced, one of the most difficult skills to develop is the ability to listen. Listening is a mental process that is intangible, making it difficult to describe. Listeners must distinguish between different sounds, comprehend the vocabulary and grammatical structures, interpret the emphasis and message, and retain and interpret all of this within the immediate context as well as a broader sociocultural context (Joseph, 1984).

Digital technology is a phenomenon that has permeated many aspects of human society. Many people work, use, and live with it, and many others try to explain how it came to be. But one thing is certain: technology has changed many situations and revolutionized this globalized world, with all the facilities now available to find any kind of information or contact someone even if they are on the other side of the world. As previously stated, digital technology has a wide range of significant effects in industries, politics, economics, and social life (Finardi \& Tyler, 2015).

Education is not different. At the time of teaching, digital technology plays an important role in providing innovative methodologies. The NICTs (New Information and Communication Technologies) curricular integration entails using technology with honesty, using technology to facilitate knowledge, using technology in the classroom, integrating technology as part of the curriculum, and using educational software to teach (Sánchez, 2018).

\section{State of the Art}

English has long been regarded as a business and travel language. According to a study published in The Babbel Magazine, approximately 1.5 billion people speak this language, accounting for $20 \%$ of the world's population (Lyons, 2017). In many pluralistic contexts and multilingual countries, English has clearly served as a language of wider communication. This language has served as a lingua franca, allowing for greater communication capacity around the world.

Argentina, Brazil, Chile, Colombia, Costa Rica, Ecuador, Mexico, Panama, Peru, and Uruguay are among the Latin American countries making significant attempts to improve their competitiveness and economic development possibilities. These are some of their biggest challenges, and one of them is improving their English skills (Cronquist \& 
Fiszbein, 2017). Ecuador began teaching English as a foreign language in 1992 (British Council, 2015), after reaching an agreement with the British Council and adopting certain curriculum revisions. Since then, Ecuador has been striving hard to improve the quality of its education, particularly in English, due to the global importance of this language. Learning English, according to Chacón (2014), provides the potential to succeed in both national and international contexts, which is why it should be studied using the most cutting-edge tools.

The purpose of this study is to see how efficient the mobile apps English Listening, and 6 Minute English are at improving listening comprehension in students learning English. Education is an important element of a person's life, yet most people associate the word "education" with a traditional classroom setting in which pupils pay attention and the teacher lectures. This idea has completely evolved in recent years. Learning is no longer limited to the classroom; new methods, particularly those that promote independent learning, are not limited to classrooms (Nadire \& Mohammad, 2018). Education is no longer solely about teaching methods, as we are now it has access to other tools such as various types of apps owing to digital technology. The English Listening app is now at version 1.1.0, with the most recent update being on October 25th, 2018. The Talk English company, which is based in the United Kingdom, offers this app, which has over 100.000 million downloads.

English Listening is a program that aims to improve students' listening skills as they learn the English language. Fill in the blanks listening lessons, describing the pictures, listening lessons, listening to famous quotations, short passages listening lessons, sentence and long paragraph dictation are among the six types of listening lessons available. Each big lesson contains 30 micro lessons based on the overall topic, for a total of 180 lessons. Each lesson was produced by ESL instructors with a master's degree in TESOL. Professional voice talent and high-quality studio equipment were used to record the audio files. Another key feature of the applications employed in this analysis is that the content rating is "Available for Everyone" regardless of the user's age. The classes are divided into six categories, each with two sublevels: beginners, intermediate, and advanced English learners (Chacón, 2014).

It's worth noting that the application requires an internet connection to function. The first lesson of the English Listening app is called "Fill in the Blanks." Students listen to the audio and fill in the blanks with the words provided. This activity is part of the beginning I lesson. The goal is to produce amusing lessons that feel like they are part of a game. After each lesson is completed, points are assigned based on how tough it was. The minimum score is 5 points, and the highest score is 20 points; it is also graded based on the progress made during the tasks. For example, in lesson 1, the participant will receive 
5 points if he listens once and responds properly, 3 points if he listens twice, and only 1 point if he listens three times or more (Google Play Store, 2018).

This source establishes that mobile learning offers a wide range of benefits, including the ability for students to study and learn whenever they want, as well as the fact that networking technology is now available in most places, allowing for successful access. People who use the program tend to strengthen their auditory system, according to one of the uses and benefits listed in the app (Nadire \& Mohammad, 2018). Also, people learning English gain a lot of vocabulary and learn how to pronounce words correctly because when they listen correctly from the start, they become accustomed to it. Furthermore, users claim that the application has aided their concentration owing to the high quality of the music they utilize, the technique, and the ease with which they may use it. Finally, one of the user contributions is that the application is incredibly user-friendly and straightforward to use.

To summarize, the English Listening mobile application has been recommended by thousands of users who have given it a positive review for the various benefits and uses that it has provided, allowing users to better their listening comprehension. According to, mobile applications are an important element of the smartphone experience as the number of smartphone users grows (Sang et al., 2014). More apps are developed to meet a greater and wider range of consumer needs, ensuring that students are always in contact with the app. The 6 Minute English app, on the other hand, is now at version 2.5.0, with the most recent update being on September 19th, 2018. The Education Apps company offers this app, which has over 500 million downloads. This app is part of the BBC Learning English Program's English Conversations (Google Play Store, 2018).

\section{It has a wide range of lessons offered in an interactive conversation format}

Although the goal of 6 Minute English is to improve listening skills, it also includes areas for learning vocabulary and grammar. The audios in this app cover a wide range of themes, including education, science, history, and geography, among others, indicating that this program contains genuine audios. The interlocutors explain the new words that were said during the audio at the end of the conversations. The app has two listening modes: online (connected to, served by, or available through a system, particularly a computer or telecommunications system, such as the Internet) and offline (not connected to or served by a system, particularly a computer or telecommunications system, such as the Internet) (Merriam-Webster Dictionary, 2018).

The same content is available in both the mobile and desktop versions of this app. If you don't have access to a speaker to listen to the audios, you can read the transcript. Another benefit of this software is that students can listen to the lecture and read the transcript at the same time. Reference The primary goal of this study is to determine the link between 
the use of the Duolingo app and the improvement of vocabulary abilities. Quantitative and qualitative methods, as well as data collecting, were employed to meet the goals of this study. The author concluded that the Duolingo app was extremely beneficial in the development of pupils' "vocabulary" because of its appropriate and engaging tasks. The major goal of this study is to see if students' listening abilities increase as a result of using podcasts and mobile learning (Ortiz, 2017).

According to the findings, podcasts have a positive impact on the learning of English, particularly in terms of listening comprehension. They also encourage children to listen in a more engaging and creative manner. The usefulness of using mobile devices to learn English as a foreign language is discussed in this (Dashtestani, 2015). This study included three types of data: interviews, questionnaires, and observations. According to the findings, mobile learning had a beneficial impact and benefit on those students in general. They had the opportunity to learn in multimedia classrooms, gain internet access, and use their devices in a variety of settings outside than the classroom (Pindeh et al., 2016).

This job aims to highlight the numerous advantages of using mobile devices, including innovation, platforms, support, and interactivity. This study was conducted in Malaysia and used empirical evidence in the form of self-administered surveys and data analysis using structural equations. Students enthusiastically accept mobile devices to learn the Kadazandusun language and its influences at the time of effective language acquisition. As a result, it is clear that using a mobile app assists pupils in improving their language skills. Aside from the classic ways, it is important to employ innovative ones that might aid in the development of language abilities (Furió et al., 2014).

This reference proposes the use of an iPhone, comparing the effectiveness of satisfaction between two methodologies at the moment of teaching: one with the use of an iPhone and the other in the traditional way. Children had a significant learning experience using the iPhone method, because students were very motivated to learn. This method helps students not only to communicate in the target language but also to use the language in real-life aspects. The impacts of Mobile-Assisted Language Learning (MALL) on listening abilities are highlighted by this author (Hea-Suk, 2011). The results of utilizing the software revealed that Mobile Assisted Language Learning can successfully increase listening skills. The purpose of this study is to see how much the listening skill improves when taught through mobile apps. The process of listening is not easy; it necessitates practice, motivation, and engagement. Using this system, pupils are able to manage this talent in a more efficient and innovative manner. Because students are required to be in contact with the target language through novel vocabulary and practice it with their classmates at each stage of this process, the use of these types of apps fosters students' listening practice. As a result, students' abilities to listen and speak appropriately improve (Mendoza, 2018). 


\section{Methodology}

This research consisted of an experimental investigation to investigate the impact of the English Listening and 6 Minute English mobile applications on listening abilities. This study involved 63 students from the Unidad Educativa Prócer Manuel Quiroga in their third year of bachelor. The research took place for 5 hours per week. Before using the English Listening and the 6 Minute English mobile applications, students performed a standardized pre-test to determine their level of listening ability. This institution's teachers conducted a survey to determine how mobile apps are used in the listening skill (Mendoza, 2018).

Table 1

Mobile applications in Listening Skill

\begin{tabular}{|l|l|l|}
\hline Frequency & Teachers & Percentage \\
\hline Always & 0 & $0 \%$ \\
\hline Sometimes & 0 & $0 \%$ \\
\hline Rarely & 1 & $20 \%$ \\
\hline Never & 4 & $80 \%$ \\
\hline Total & 5 & $100 \%$ \\
\hline
\end{tabular}

Source: Mendoza (2018)

Figure 1

Mobile applications in Listening Skill

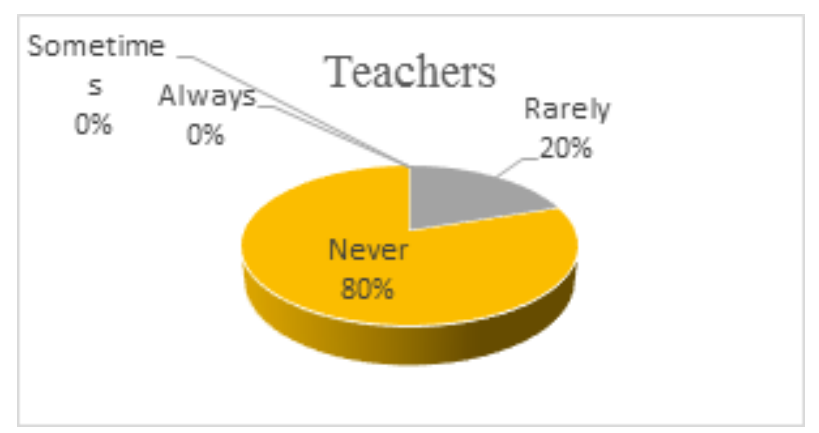

Note: The process teachers apply the Mobile applications in the listening skill development. Fuente: Unidad Educativa Prócer Manuel Quiroga.

According to the findings, $80 \%$ of the respondents to a survey of four teachers said they never use mobile applications to help their pupils improve their listening comprehension skills. The remaining 20\% stated they don't use those kinds of apps very often. It's concerning because pupils aren't receiving classes that use cutting-edge methodologies 
and strategies. Furthermore, in the process of learning a foreign language, the ability to listen has lost its significance. There is a lack of expertise, space, and materials to effectively develop this skill.

\section{Results}

The Wilcoxon test is used to get a deep analysis of the applied methodology at Unidad Educativa Prócer Manuel Quiroga, with students from the third year of baccalaureate, in order to develop the listening skill comprehension through the use of mobile applications, taking into account the results obtained in the Pre-test and Post-test.

\section{Figure 1}

Wilcoxon Signed Ranks test

Ranks

\begin{tabular}{|ll|r|r|r|}
\hline & \multicolumn{1}{|c|}{ Ranks } \\
\hline & $\mathrm{N}$ & Mean Rank & \multicolumn{1}{c|}{$\begin{array}{c}\text { Sum of } \\
\text { Ranks }\end{array}$} \\
\hline Postest - Pretest & Negative Ranks & $7^{3}$ & 11,93 & 83,50 \\
& Positive Ranks & $46^{\mathrm{b}}$ & 29,29 & 1347,50 \\
& Ties & $10^{\circ}$ & & \\
& Total & 63 & & \\
\hline
\end{tabular}

At first positive and negative ranks are shown. There are 7 negative ranks and 46 positive ranks. The total number is 63 .

Figure 2

Listening skill pre- post-test

\begin{tabular}{|l|r|}
\hline & \multicolumn{1}{|c|}{$\begin{array}{c}\text { Postest- } \\
\text { Pretest }\end{array}$} \\
\hline$Z$ & $-5,726^{\mathrm{b}}$ \\
Asymp. Sig. (2-tailed) &, 000 \\
\hline
\end{tabular}

The figure 3 shows the reason value $Z$, and the significance value. In this case the significance value is $-5,726$. The Wilcoxon test establishes in its theory that, if the significance value is less than 0.005 the null hypothesis must be declined as in this case. So, the significance shows a total of 0.000 ; it is less than 0.5 , giving a $95 \%$ of rejection to the null hypothesis. 


\section{Conclusions}

- English Listening and 6 Minute English are two mobile applications that teachers may trust and use to help students improve their listening comprehension. These programs offer a wide range of interactive, innovative, and instructive listening activities. Their systems are trustworthy and include accurate information that can be shared in a classroom setting.

- The suggested mobile applications were well received by students in their third year of baccalaureate. Due to a lack of resources, it was obvious that listening skills at the Unidad Educativa Prócer Manuel Quiroga were being developed using traditional methods and that kids did not have much practice in all of the abilities, particularly listening. In light of these factors, English Listening and 6 Minute English were found to be beneficial in the development of listening comprehension. Students were attracted to their structure, approach, and resources, and they mastered the language quickly.

- These characteristics made both the learner and the teacher feel at ease and encouraged to improve their listening skills. Technology has been used to teach English before, but English Listening and 6 Minute English are two new digital entrants that help English learners enhance their listening skills.

\section{References Bibliography}

British Council. (2015). English in Ecuador.

Chacón, R. (2014). El aprendizaje de idiomas mediante MOOCs. MOOCs (pág. 3).VI Jornadas de Redes de Investigación en Innovación docente de la UNED.

Cronquist, K., \& Fiszbein, A. (2017). English Language Learning in Latin America. Latin América.

Dashtestani, R. (2015). Moving bravely towards mobile learning: Iranian students' use of mobile devices for learning English as a foreign language. Routledge, 20.

Finardi, K., \& Tyler, J. (2015). The Role of English and Technology in The Internationalization of Education: Insights from The Analysis of Moocs. Brazil: UFES.

Furió, D., Seguít, I., \& Vivó, R. (2014). Mobile learning vs. traditional classroom lessons: a comparative study. Journal Of Computer Assisted Learning, 13. 
Google Play Store. (15 de 10 de 2018). Talk English. English Listening App: https://play.google.com/store/apps/details?id=com.talkenglish.listening\&hl=en_ US

Hea-Suk, K. (2011). Emerging Mobile Apps to Improve English Listening Skills. Seoul Women's University, 20.

Irzsa. (9 de junio de 2012). Prácticas sociales del lenguaje. Habilidades lingüísticas. Escuchar, hablar, leer $\quad$ y escribir. https://irzsa.wordpress.com:https://irzsa.wordpress.com/2012/06/09/habilidadeslinguisticas-escucharhablar-leer-y-escribir/

Joseph, W. (1984). Strategies for Teaching Second Language Listening Comprehension. Pennsylvania.

Lyons, D. (26 de Julio de 2017). Babbel Magazine. https://www.babbel.com/en/magazine/how-many-people-speak-english-andwhere-is-it-spoken

Mendoza, V. (2018) English Listening and 6 Minute English APPS for the Listening Skill Comprehension.

Merriam-Webster Dictionary. (2018). Online and Offline Definitions.

Nadire, C., \& Mohammad, M. A.-M. (2018). Mobile system for flexible education. Science Direct, 5.

Ortiz, A. (agosto de 2017). Uso e implementación de la herramienta Vodcast para el desarrollo de la destreza del Listening. Quito, Pichincha, Ecuador.

Pindeh, N., Mohd, N., \& Mohd, N. (2016). User Acceptance on Mobile Apps as an Effective Medium to Learn Kadazandusun Language. Science Direct, 372.

Sánchez, J. (2018). Integración Curricular de las TICs: Conceptos e Ideas. Chile: Departamento de Ciencias de la Computación.

Sang, C., Doyle, Y., \& Eun, K. (2014). Antecedents of mobile app usage among smartphone users. Journal of Marketing Communications, 20.

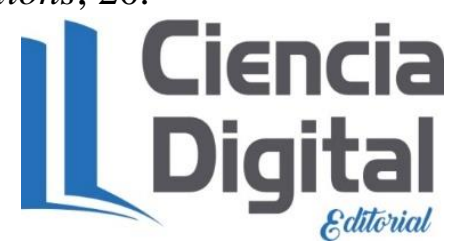


El artículo que se publica es de exclusiva responsabilidad de los autores y no necesariamente reflejan el pensamiento de la Revista Conciencia Digital.

\section{Liencia}

El artículo queda en propiedad de la revista y, por tanto, su publicación parcial y/o total en otro medio tiene que ser autorizado por el director de la Revista Conciencia Digital.
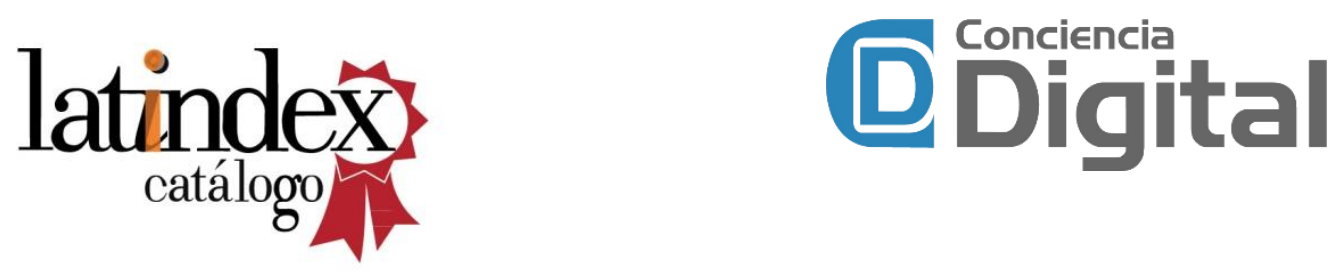

Indexaciones

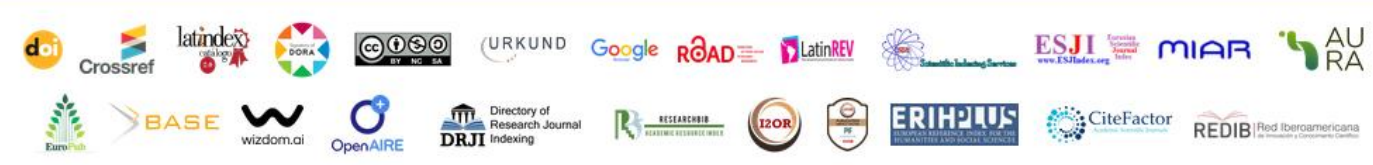

